\title{
Effects of chronic consumption of green tea on weight and body fat distribution of Wistar rats evaluated by computed tomography ${ }^{1}$
}

\author{
Renata Attademo Raso', Rebecca Rodrigues Bergamaschini Paim", Sérgio Veloso Brant Pinheiro"', \\ Wilson Campos Tavares Júnior ${ }^{\prime v}$, Leonardo de Souza Vasconcellos ${ }^{\vee}$, Luiz Ronaldo Albertivı
}

\begin{abstract}
'Master in Biomedicine, Instituto de Ensino e Pesquisa da Santa Casa, Belo Horizonte-MG, Brazil. Technical procedures; acquisition, analysis and interpretation of data; statistical analysis.

"Graduate student, Faculty of Medicine, Universidade Federal de Minas Gerais (UFMG), Belo HorizonteMG, Brazil. FAPEMIG scholarship. Acquisition; analysis and interpretation of data; manuscript preparation.

I'PhD, Biological Sciences, Instituto de Ciências Biológicas. Associate Professor, Department of Pediatrics, UFMG, Belo Horizonte-MG, Brazil. Scientific and intellectual content of the study.

"Vhysician, Assistant of Radiology, Hospital das Clínicas, UFMG, Belo Horizonte-MG, Brazil. Technical procedures; analysis, interpretation and acquisition of data.

vPhD, Associate Professor, Department of Propedeutics, Faculty of Medicine, UFMG, Belo Horizonte-MG, Brazil. Conception and design of the study, critical revision.

VIPhD, Associate Professor, Department of Surgery, Faculty of Medicine, UFMG, and Instituto de Ensino e Pesquisa da Santa Casa, Belo Horizonte-MG, Brazil. Analysis and interpretation of data, critical revision, final approval.
\end{abstract}

\begin{abstract}
Purpose: To evaluate the effects of chronic consumption of green tea on body weight and distribution of visceral fat by Computed tomography in female Wistar rats.

Methods: Wistar rats were divided into control group $(n=5)$, which received water and feed ad libitum, and green tea group $(n=8)$, in which water has been replaced by green tea. The animals were weighed weekly and Computed Tomography was used at the beginning $\left(1^{\text {st }}\right.$ week) and end $\left(18^{\text {th }}\right.$ week) of the experiment for evaluating the distribution of visceral fat. The animals were followed for 18 weeks.

Results: There was no significant difference in body weight between the groups. However, there was significant difference in visceral fat area. The green tea group had less visceral fat area at the end of the experiment, $3.67 \pm 1.2 \mathrm{~cm}^{2}$, while the control group showed an area of $6.25 \pm 2.2 \mathrm{~cm}(\mathrm{p}=0.00)$.
\end{abstract}

Conclusions: Chronic consumption of green tea leads to decreased visceral adipose tissue area.

Key words: Tea. Metabolism. Abdominal Fat. Tomography. Rats. 


\section{Introduction}

Green tea is widely consumed in the world and has attracted attention from the scientific community and the general public for its beneficial health effects. Among the effects attributed to the green tea are included prevention of cancer and cardiovascular disease, anti-inflammatory actions, antioxidant, antibacterial, antiviral, neuroprotective effects, cholesterol reducer, body fat reducer and assistance in the treatment and prevention of obesity and associated diseases, such as diabetes and dyslipidemia ${ }^{1,2}$.

From the Camellia sinensis plant are extracted the green tea and also the black tea and Oolong tea. Green tea is not fermented, unlike the other two, allowing the conservation of polyphenol, the main responsible for their beneficial effects ${ }^{1-4}$.

The polyphenolic components make up $30 \%$ of the green tea composition, and include flavanols, flavandiols, phenolic acids and flavonoids ${ }^{1,5}$. The main polyphenol found in green tea and catechins are the predominant flavonoids, corresponding to about $7 \%$ of their compounds. Catechins and flavonoids are known for their antioxidant, anti-inflammatory, anti-allergic and anticarcinogenic effects ${ }^{3,6}$. There are four major catechins found in green tea: (-) - epicatechin (EC), (-) - epicatechin 3-gallate (GEC), (-) - epigalatocatequina (EGC) and 3-gallate epigalotequina (GEGC). The biggest tea polyphenolic constituent is GEGC ( $11 \%$ of the total composition) and this substance has the highest antioxidant activity among the aforementioned catechins ${ }^{1-4,6}$.

One of the main positive effects of green tea on health, and the subject matter of this article, its effect on body fat. Catechins are responsible for this effect and promote fat loss by increasing energy expenditure, fat oxidation and decreased lipid absorption by the intestine $e^{1-3,5-9}$.

The increased energy expenditure and fat oxidation is caused by stimulation of $\beta$-adrenergic receptors in adipose tissue. Choo et al. ${ }^{10}$ demonstrated an increased metabolic rate in rats with high fat diet which began to consume green tea, that this increase was prevented by the use of blocking betaadrenergic receptors. ]

It has been shown that green tea also acts on body weight reduction promoting absorption of lipids. Modulation of dietary fat absorption was observed after treatment with GEGC, generating increase in fecal weight and fecal lipid content in mice which is dose-dependent ${ }^{11-13}$.

There is also the possibility that the green tea promotes change in eating habits. Studies showed reduced food intake resulting from ingestion of tea or intraperitoneal administration GEGC ${ }^{14,15}$. However, most studies showed no change in feeding practices in mice or humans ${ }^{11-13,16}$.

Despite some differences regarding the mechanisms involved in the effects of green tea on body fat, most studies showed its efficacy in reducing body fat or prevention of its increase $6,8-15,17,18$.

The body fat can be divided in visceral adipose tissue and subcutaneous adipose tissue. Visceral adipose tissue presents a greater association with metabolic diseases, is considered an independent risk factor for cardiovascular disease and is related to some cancers, such as breast, colon and prostate ${ }^{19,20}$.

$$
\text { Computed tomography }
$$

is considered a gold standard for the measurement of subcutaneous adipose tissue and in particular visceral adipose tissue ${ }^{19-21}$.

This study aimed to assess changes body weight and in the distribution and volume of visceral fat resulting from the chronic consumption of green tea in Wistar rats. 


\section{- Methods}

Legal and ethical aspects were observed as the determination of Law 11.794 of October 8, 2008 which provides for procedures for the scientific use of animals and Ethical Principles for the Use of Experimental Animals and the experiment was approved by the Ethics Committee and Animal experimentation (CETEA) of the Universidade Federal de Minas Gerais (certificate 149/2011).

The animals were obtained from the Animal Facility of the UFMG Institute of Biological Sciences and the work was performed at the Animal Experimental Center of the UFMG University of Medicine.

Were used 13 female Wistar rats lineage, weighing between 150 to $180 \mathrm{~g}$ initially. The animals were identified by dashes in the tail with a dermatographic pen and were placed in polypropylene cages with stainless steel lid. The ambient temperature, relative humidity and photoperiod (6am to $6 \mathrm{pm}$ ) were controlled.

The animals were randomly assigned into two groups:

- Group 1: control ( $n=5)$

- Group 2: Green tea $(n=8)$

Both groups received standard rat chow at ease. The control group received unlimited water and green tea group received green tea instead of water, also at ease.

Dried leaves of Camellia sinensis were used to prepare the tea, the brand Love to Life Natural Products Ltda ${ }^{\circledR}$. The preparation was carried out as follows: $10 \mathrm{~g}$ of dried leaves of Camellia sinensis were added to one liter of room temperature water being at rest for one hour. Then the tea was brewed and offered to animals in the green tea group in suitable containers (bottles) properly sanitized and intended exclusively for this use. The tea was prepared and changed daily.

For analysis of visceral adipose tissue, the rats were subjected to $\mathrm{CT}$ in the first and the eighteenth week of the experiment. Before the procedure the rats were anesthetized with ketamine $(60 \mathrm{mg} / \mathrm{kg}$ ) and xylazine $(9 \mathrm{mg} / \mathrm{kg}$ ) intramuscular injection. The animals were then positioned supine in the device table.

Then we carried out the protocol for image acquisition. We used the CT scanner device BrightSpeed $\mathrm{GE}^{\circledR} 16$ detectors, Wisconsin, USA. The images were obtained via helical acquisition protocol, through axial slices of $0.6 \mathrm{~mm}$ without contrast. The axial sections of the caudal region at the bilateral renal lower pole in abdominal retroperitoneal topography were used since this is the region where it is observed fatty tissue and the mesenteric fat appears sparse. The selected image, delimited up area with fat density representing the attenuation range in Hounsfield units (HU), considered between -120 to $-80 \mathrm{HU}$. The OsiriX software was used.

Body weight of the animals was monitored weekly, using digital electronic scale CEF - Fernando Filizola Balanças ${ }^{\circledR}, \mathrm{C} 15$ model. Weighing was always held on the same day of the week and at the same time.

Statistical analysis was performed using Prism 4.0 software. Results were expressed as a measure \pm standard deviation (SD). We used the Kolmogorov-Smirnov test to evaluate normality. Comparisons between groups were performed using Student's t test. Statistical analysis was performed with a $95 \%$ level of significance, therefore, the values of $p<0.05$ were assumed to be statistically significant.

\section{- Results}

All animals survived the 18 weeks of the experiment.

In the first week of the experiment, as the animals have been distributed among groups randomly, there was no significant difference in body weight between the groups. At the end of eighteen weeks of the experiment, it was also no significant 
difference in body weight, and the animals of the control group showed a weight of $274.8 \pm$ $21.2 \mathrm{~g}$ (mean \pm SD) and the animals of green tea group $259 \mathrm{~g} \pm 13.2($ mean $\pm S D)(p=0.06)$ (Figure 1).

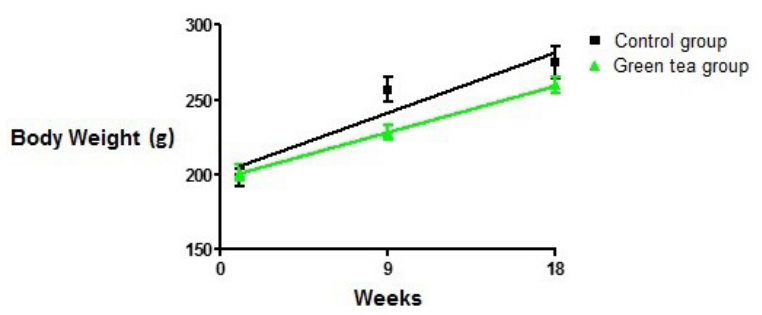

Figure 1 - Body weight of mice (g) from the control group and green tea in the first, ninth and eighteenth weeks of experiment. The graphic shows the weight gain of both groups throughout the experiment, with no significant difference in final weight between groups $(p=0.06)$.

In relation to the area of visceral fat assessed by CT, there was no significant difference between the groups at the beginning of the experiment. After 18 weeks, green tea group showed lower area of adipose tissue, $3.67 \pm 1.2 \mathrm{~cm}^{2}$ compared to the control group, $6.25 \pm 2.2 \mathrm{~cm}^{2}(p=0.001)$ and this difference was significant (Figures 2 and 3 ).

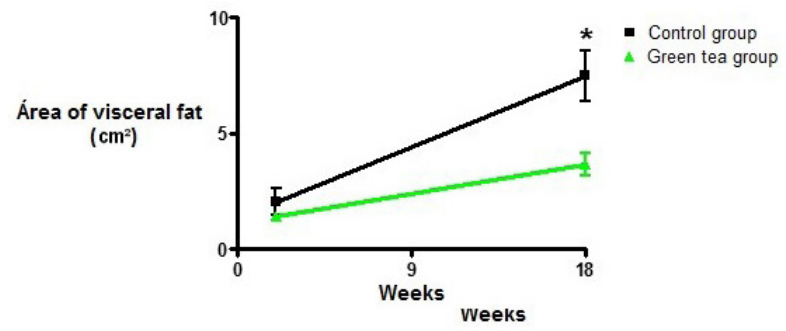

Figure 2 - Area $\left(\mathrm{cm}^{2}\right)$ of visceral fat from the control group and green tea on the first and eighteenth week of experiment, between the lumbar vertebrae $L 4$ and L5. Both groups presented increased visceral fat area over 18 weeks, but the control group presented a more expressive increase, resulting in a greater area of visceral fat at the end of the experiment $(p=0.001)$.

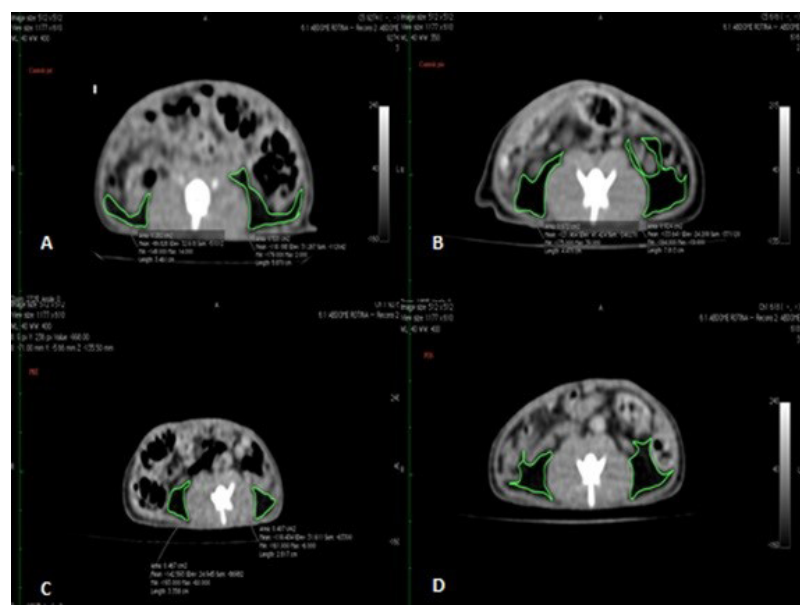

Figure 3 - Area $\left(\mathrm{cm}^{2}\right)$ of visceral fat measured by CT scan Control Groups and Green Tea. Visceral fat area of a control group member in the 2 nd week of experiment (A); Visceral fat area of a control group member in the 18th week of experiment (B); Visceral fat area of a Green Tea Group member in the 2nd week of experiment (C); Visceral fat area of a Green Tea Group in the 18th week of the experiment (D).

In the animals of both groups there was an increase of visceral fat in relation to body weight. However, in the control animals there was a greater gain in visceral fat in proportion to body weight when compared to the green tea group, and this difference was statistically significant $(p=0.01)$ (Figure 4).

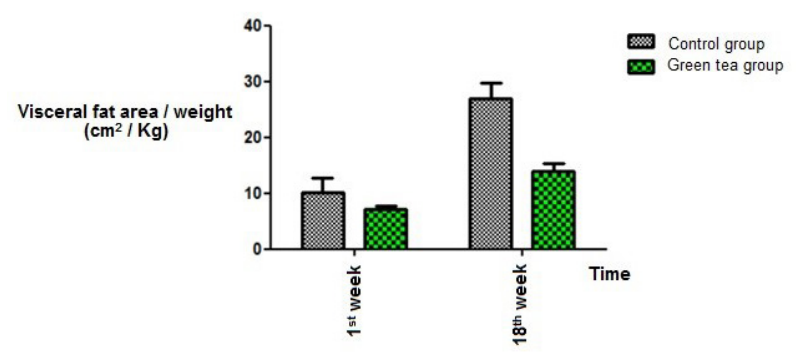

Figure 4 - Relationship between visceral fat area $\left(\mathrm{cm}^{3}\right)$ and weight $(\mathrm{kg})$ from the control group and green tea at the beginning and end of the experiment, Showed that visceral fat gain in relation to body weight gain was higher in the control group $(p=0.01)$. 


\section{- Discussion}

Many studies have shown the beneficial effects of green tea on body weight reduction as a result of its consumption or monitoring its polyphenolic compounds $s^{6,8-18}$.

Vera-Cruz et al. ${ }^{8}$ showed significant loss of body weight in obese animals treated with Green. Monteiro et al. ${ }^{22}$ found that prolonged intake of green tea, adult Wistar rats gained less weight when compared with the control group. These studies, and others, showed the use of green tea in the treatment and prevention of overweight ${ }^{10-16}$. However, the change in fat distribution has not been evaluated and the analysis of this parameter can contribute to a better understanding of the mechanisms by which green tea acts.

In the present study, we evaluated not only the weight change, but the change in abdominal fat area promoted by the chronic use of green tea, by computed tomography.

The obesity, characterized by excessive body fat, is an endemic disease and is related to several comorbid, such as cardiovascular diseases, diabetes mellitus, dyslipidemia, osteomuscular pains and cancers, especially breast, colon and prostate. Visceral adipose tissue is more related to these diseases when compared to subcutaneous adipose tissue ${ }^{19,20}$.

The measures most commonly used to diagnose excess body fat and risk assessment are associated with the Body Mass index (BMI) and abdominal circumference measurement. These are the most used methods by being easy to apply, innocuous and affordable, but do not provide accurate measurement of the distribution of body fat, in addition to having other limitations ${ }^{22}$. Other techniques allow the measurement of body fat, as a measure of the skin fold thickness, Bioimpedance analysis, Magnetic Resonance and Computed Tomography (CT). CT is considered golden standard for assessing the distribution of body fat, but use of CT in clinical practice and in epidemiological experimental studies is limited, especially due to radiation and to its cost.

Computed tomography as a tool for assessing body fat distribution has its own established use in humans, for which measurements of sensibility, degree of reliability and specificity, have been evaluated. For rats and mice these characteristics are not yet well established, but there are studies that seek to validate the accuracy of CT in the evaluation of adipose tissue in mice, primarily due to the need of using animal model for studies related to fat stores and the pathophysiological differences related to them ${ }^{23}$.

Hillebrand et al. $^{23}$ performed a series of experiments, including tissue weight comparisons of connective abdominal and subcutaneous adipose dissected with the estimated by CT. Through these studies it was possible to verify some differences between human and murine, for example, a poorer estimation of visceral fat area when this is performed by automatic analysis, an overestimation of adipose tissue by $10 \%$ (and this difference remained constant) and characterization erroneous of lung tissue with the abdominal adipose tissue. However these changes have proven amenable to simple fixes and other results of this series of experiments demonstrated that CT is an accurate method, reliable and sensitive to evaluate adipose tissue distribution in rats and mice.

Costa et al. ${ }^{24}$ also demonstrated that CT is an effective method for quantifying the areas of visceral adipose tissue, to evaluate mice pups malnourished. [24] Luburra et al. ${ }^{25}$, a study conducted to quantify the adipose tissue in lean and obese mice by CT showed that this method provides good result in measure the quantification of total adipose tissue, visceral and subcutaneous tissue, allowing the accomplishment of longitudinal studies of obesity in mice.

In the present study the axial caudal of the region to the bilateral renal inferior pole in abdominal retroperitoneal topography were used since this is the region where it is observed 
fatty tissue and the mesenteric fat appears sparse. At the beginning of the experiment, the analysis of CT showed no significant difference in the area and in fat distribution between the two groups $(p=0.25)$. At the end of 18 weeks, CTshowed significant differences in fat distribution between the groups, and the animals who consumed green tea had a lower area of abdominal adipose tissue ( $p=0.01$ ), suggesting the effect green tea in lowering of the fat compartment.

During the 18-week period, the animals of both groups had an increase in weight and visceral fat, resulting from the growth of the animals, which at the beginning of the experiment were young. However, the visceral fat gains proportional to the weight of the animals were different between the groups. The green tea group had a smaller gain in visceral fat compared to body weight, resulting in a smaller area of visceral fat per kilogram body weight at the end of the experiment compared to the control group ( $p: 0.01)$.

Green tea acts on promoting fat oxidation and increased metabolic rate. Saetan et al. ${ }^{11}$ demonstrated that GEGC generates an increase in the expression of related genes in fatty acid oxidation in rats, which may explain the effect of GEGC in reducing body weight by increasing fat oxidation. This effect occurs through stimulation of the adrenergic $\beta$ receptors by GEGC, as demonstrated by Choo et al. $^{10}$.

Visceral adipose tissue is the body fat compartment considered as the most metabolically active, when compared to subcutaneous adipose tissue as it is the most sensitive to the lipolytic action of catecholamines on $\beta$ receptors adrenergic ${ }^{20}$. So that, the effect of catechins green tea on $\beta$-adrenergic receptors is probably responsible for the significant reduction of visceral fat observed in this study.

In relation to body weight, there was no significant difference between the groups, demonstrating that green tea did not act on the total weight reduction in this study. However, the effect of tea on the visceral fat may be more important than the reduction of the body weight measured in an isolated manner, when treating obesity and associated diseases. Excess weight may be related to other tissues and direct measurement of visceral fat can better predict on risks associated with obesity.

Demonstrating the reduction of visceral adipose tissue in female Wistar rats performed in this study, contributes to knowledge about the effects and mechanisms of green tea on body fat. However, many studies, especially related to bioavailability, absorption, metabolism, toxicity and prolonged consumption of green tea and its polyphenolic compounds, especially in humans, are necessary to be able to use green tea as a treatment and preventative measure of obesity.

\section{- Conclusions}

Chronic consumption of green tea leads to decreased visceral adipose tissue area analyzed by CT scan.

\section{References}

1. Chacko SM, Thambi PT, Kuttan R, Nishigaki I. Beneficial effects of green tea: a literature review. Chin Med. 2010;5:13. doi: 10.1186/1749-8546-5-13.

2. Hursel R, Viechtbauer W, WesterterpPlantenga MS. The effects of green tea on weight loss and weight maintenance: a metaanalysis. Int J Obes (Lond). 2009;33(9):95661. PMID: 19597519.

3. El-Shahawi MS, Hamza A, Bahaffi SO, AlSibaai AA \& AbduljabbarTN. Analysis of some selected catechins and caffeine in green tea by high performance liquid chromatography. Food Chem. 2012;134(4):2268-75. doi: 10.1016/j.foodchem.2012.03.039.

4. Lamarão RDC, Fialho E. Aspectos funcionais das catequinas do chá verde no metabolismo celular e sua relação com a redução da gordura corporal. Rev Nutr. 
2009;22(2):257-69. doi: 10.1590/s141552732009000200008.

5. De Morais SM, Cavalcanti ES, Costa SM, Aguiar LA. Ação antioxidante de chás e condimentos de grande consumo no Brasil. BrazJPharmacogn.2009Mar;19(1b):315-20. doi: 10.1590/S0102-695X2009000200023.

6. Singh BN, Shankar S, Srivastava RK. Green tea catechin, epigallocatechin-3-gallate (EGCG): mechanisms, perspectives and clinical applications. Biochem Pharmacol. 2011;82(12):1807-21. doi: 10.1016/j. bcp.2011.07.093.

7. Meydani M, Hasan ST. Dietary polyphenols and obesity. Nutrients. 2010;2(7):737-51. doi: $10.3390 /$ nu2070737.

8. Vera-Cruz M, Nunes E, Mendonça L, Chaves É, Fernandes ML. Antiobesity effects of green tea (Camelia sinensis) in high caloric diet-induced obese rats. J Bras Patol Med Lab. 2010;46(5):407-13. doi: 10.1590/ s1676-24442010000500010.

9. Zheng G, Sayama K, Okubo T, Juneja LR, Oguni I. Anti-obesity effects of three major components of green tea, catechins, caffeine and theanine, in mice. In Vivo. 2004;18(1):55-62. PMID: 15011752.

10. Choo JJ. Green tea reduces body fat accretion caused by high-fat diet in rats through beta-adrenoceptor activation of thermogenesis in brown adipose tissue. J Nutr Biochem. 2003;14(11):671-6. doi: 10.1016/j.jnutbio.2003.08.005.

11. Sae-tan S, Grove KA, Kennett MJ, Lambert JD. (-)-Epigallocatechin-3-gallate increases the expression of genes related to fat oxidation in the skeletal muscle of high fatfed mice. Food Funct. 2011;2(2):111-6. doi: 10.1039/c0fo00155d.

12. Wolfram S, Raederstorff D, Wang $Y$, Teixeira SR, Elste V, Weber P. TEAVIGOTM (epigallocatechin gallate) supplementation prevents obesity in rodents by reducing adipose tissue mass. Ann Nutri Metab. 2005;49(1):54-63. doi: 10.1159/000084178.

13. Klaus S, Pültz S, Thöne-Reineke C, Wolfram S. Epigallocatechin gallate attenuates dietinduced obesity in mice by decreasing energy absorption and increasing fat oxidation. Int J Obes (Lond). 2005;29(6):61523. doi: $10.1038 /$ sj.ijo.0802926.

14. Sayama K, Lin S, Zheng G, Oguni I. Effects of green tea on growth, food utilization and lipid metabolism in mice. In Vivo. 2000;14(4):481. PMID: 10945161.

15. Kao YH, Hiipakka RA, Liao S. Modulation of endocrine systems and food intake by green tea epigallocatechin gallate. Endocrinology. 2000;141:980-87. doi: 10.1210/en.141.3.980.

16. Gondoin A, Grussu D, Stewart D, McDougall GJ. White and green tea polyphenols inhibit pancreatic lipase in vitro. Food Res Int. 2010;43:1537-44. doi: 10.1016/j. foodres.2010.04.029.

17. Dulloo AG, Duret C, Rohrer D, Girardier L, Mensi N, Fathi M, Chantre P, Vandermander J. Efficacy of a green tea extract rich in catechin polyphenols and caffeine in increasing 24-h energy expenditure and fat oxidation in humans. Am J Clin Nutr. 1999;70(6):1040-5. PMID: 10584049.

18. Colon M, Nerin C. Molecular interactions between caffeine and catechins in green tea. J Agric Food Chem. 2014;62(28):677783. doi: $10.1021 / j f 5011287$.

19. Jensen MD, Ryan DH, Apovian CM, Ard JD, Comuzzie AG, Donato KA, Frank B, Hubbard VS, Jakicic JM, Kushner RF, Loria CM, Millen BE, Nonas CA, Pi-Snyer FX, Stevens J, Stevens VJ, Wadden TA, Wolfe BM, Yanovski SZ. AHA/ACC/TOS Guideline for the management of overweight and obesity in adults. Circulation. 2014;129(25):102-38. doi: $10.3904 / \mathrm{kjm} .2014 .87 .2 .136$.

20. Hermsdorff HH, Monteiro JB. Gordura visceral, subcutânea ou intramuscular: onde está o problema? Arq Bras Endocrinol Metab. 2004;48(6):803-11. doi: 10.1590/ s0004-27302004000600005.

21.Vasques AC, Priore SE, Rosado LE, Franceschini SD. Utilização de medidas antropométricas para a avaliação do acúmulo de gordura visceral. Rev Nutr. 2010;23(1)107-18. doi: 10.1590/s141552732010000100012.

22. Monteiro R, Assunção $M$, Andrade JP, Neves D, Calhau C, Azevedo I. Chronic green 
tea consumption decreases body mass, induces aromatase expression, and changes proliferation and apoptosis in adult male rat adipose tissue. J Nutr. 2008;138:2156-63. PMID: 18936213.

23. Hillebrand JJ, Langhans W, Geary N. Validation of computed tomographic estimates of intra-abdominal and subcutaneous adipose tissue in rats and mice. Obesity. 2010;18(4)848-53. doi: 10.1038/oby.2009.34.

24. Costa CA, Alves EG, Gonzalez GP, Barbosa $T B$, Lima VD, Nascimento R, Monteiro
AMV, Moura EG, Saba CCAN. Computed tomography in the evaluation of abdominal fat distribution associated with a hyperlipidic diet in previously undernourished rats. Radiol Bras. 2007;40(5):337-40. doi: 10.1590/s0100-39842007000500011.

25. Lubura M, Hesse D, Neumann N, Scherneck $S$, Wiedmer $P$, Schürmann A. Non-invasive quantification of white and brown adipose tissues and liver fat content by computed tomography in mice. PloS One. 2012;7(5):e37026. doi: 10.1371/journal. pone.0037026.

\section{Correspondence:}

Dr. Luiz R Alberti

Departamento de Cirurgia, UFMG

Avenida Francisco Sales, 1.111/90 andar, BI D

30140-040 Belo Horizonte - MG Brasil

Tel.: (55 31)9955-0400

luizronaldoa@yahoo.com.br

Received: Jan 16, 2017

Review: Mar 15, 2017

Accepted: Apr 18, 2017
Conflict of interest: none

Financial sources: FAPEMIG (Grant APQ-0001113), and Pró-Reitoria de Pesquisa da UFMG

${ }^{1}$ Research performed at Instituto de Ensino e Pesquisa da Santa Casa, and Universidade Federal de Minas Gerais (UFMG), Belo Horizonte-MG, Brazil. 